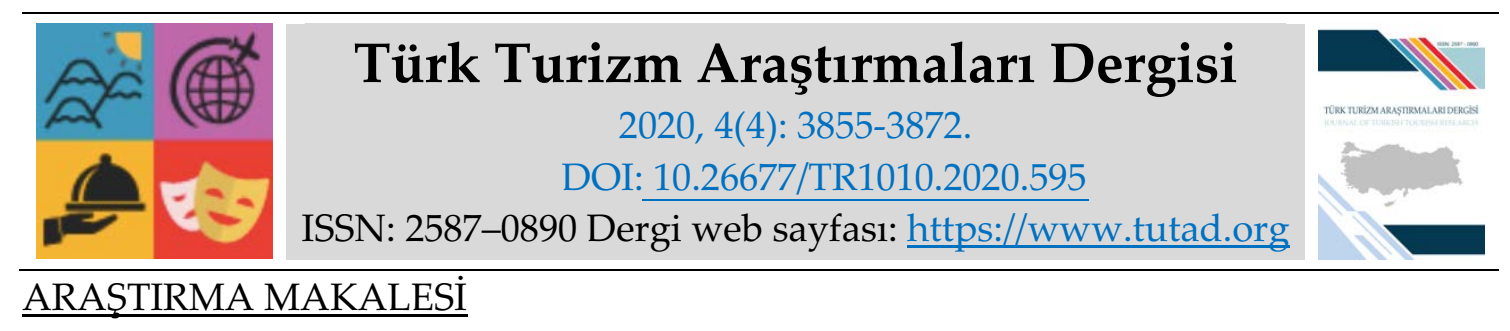

\title{
Festival Algısı ve Memnuniyet Üzerine Bir Araştırma: Adana ve Antalya Film Festivali Örneği
}

Dr. Öğr. Üyesi Aylin AKTAŞ ALAN, Antalya AKEV Üniversitesi, Sanat ve Tasarım Fakültesi, Antalya, e-posta: aylin.alan@akev.edu.tr ORCID: https://orcid.org/0000-0003-4652-7011

Arş. Gör. Gaye KIZILCALIOĞLU, Antalya AKEV Üniversitesi, Sanat ve Tasarım Fakültesi, Antalya, e-posta: gaye.kizilcalioglu@akev.edu.tr ORCID: https://orcid.org/0000-0003-2995-6105

Öz

Etkinlikler genelde turistik bir çekicilik olarak kabul edildiğinden birçok destinasyon ulusal ve uluslararası düzeyde etkinlikler düzenleme çabası içerisindedir. Destinasyonların tanıtılmasında, imajın geliştirilmesinde, ekonomik ve sosyal yararların sağlanmasında katkı sağlayan festivaller en önemli etkinlikler arasında yer almaktadır. Bu araştırma ile 24. Uluslararası Adana Film Festivali'ni ve 54. Antalya Uluslararası Altın Portakal Film Festivali'ni ziyaret eden katılımcıların festival algısı ve festivalden memnuniyet düzeyleri belirlenmeye çalışılmıştır. Bu amaçla festival zamanlarında rastlantısal örnekleme tekniği ile bir anket çalışması gerçekleştirilmiş ve her bir festivalde 400 'er kişi olmak üzere toplamda 800 kişiye ulaşılmıştır. Araştırma kapsamında yapılan CHAID analizi sonucunda festival memnuniyetini en iyi yordayan değişkenin bireysel ve kentsel yararlar olduğu; demografik değişkenler açısından ise en iyi yordayan değişkenin yaş olduğu tespit edilmiş̧ir. Ayrıca katılımcıların memnuniyetleri üzerinde etkili olan festival algisı boyutlarının Uluslararası Antalya ve Adana Film Festivalleri'nde farklılaştığı bulgulanmıştır. Uluslararası Adana Film festivali memnuniyeti üzerinde sosyal ve kültürel yararlar ile bireysel ve kentsel yararlar etkili olurken Antalya Film festivalinde yalnızca bireysel ve kentsel yararlar etkili olmuştur.

Anahtar Kelimeler: Festival Algısı, Festival Memnuniyeti, CHAID Analizi, Adana Film Festivali, Antalya Film Festivali.

Makale Gönderme Tarihi: 03.08.2020

Makale Kabul Tarihi: 10.10 .2020

Önerilen Atıf:

Aktaş Alan, A. ve Kızılcalıoğlu, G (2020). Festival Algısı ve Memnuniyet Üzerine Bir Araştırma: Adana ve Antalya Film Festivali Örneği, Türk Turizm Araştırmaları Dergisi, 4(4): 3855-3872.

(C) 2020 Türk Turizm Araştırmaları Dergisi. 


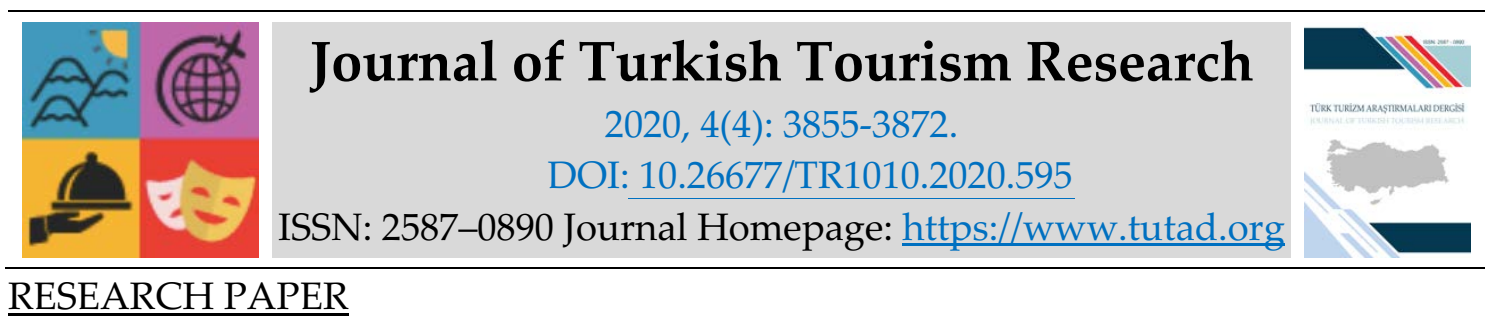

\title{
An Investigation on Festival Perception and Satisfaction: The Case of Adana and Antalya Film Festival
}

Assistant Prof. Dr. Aylin AKTAŞ ALAN, Antalya AKEV University, Faculty of Art and Design, Antalya, e-mail: aylin.alan@akev.edu.tr ORCID: https://orcid.org/0000-0003-4652-7011

Research Assistant Gaye KIZILCALIOĞLU, Antalya AKEV University, Faculty of Art and Design, Antalya, e-mail: gaye.kizilcalioglu@akev.edu.tr

ORCID: https://orcid.org/0000-0003-2995-6105

\begin{abstract}
Since the activities are generally accepted as a tourist attraction, many destinations try to organize events at national and international levels. Festivals that contribute to the promotion of destinations, the development of the image and the economic and social benefits are among the most important activities. With this research, the perception of the festival and satisfaction levels of the participants who visited 24th International Adana Film Festival and 54th Antalya International Orange Film Festival were determined. For this purpose, a survey was conducted with the random sampling technique during festival times and a total of 800 people were reached, 400 people in each festival. As a result of the CHAID analysis conducted within the scope of the research, it was found that the variable that best predicts festival satisfaction is individual and urban benefits; in terms of demographic variables, age was found to be the best predictor variable. In addition, it has been found that the dimensions of the festival perception, which affect the satisfaction of the participants, differ in the International Antalya and Adana Film Festivals. While social and cultural benefits and individual and urban benefits were effective on the satisfaction of the International Adana Film Festival, only individual and urban benefits were effective in the International Antalya Film Festival.
\end{abstract}

Keywords: Festival Perception, Festival Satisfaction, CHAID Analysis, Adana Film Festival, Antalya Film Festival.

Received: 03.08.2020

Accepted: 10.10 .2020

Suggested Citation:

Aktaş Alan, A. and Kızılcalığlu, G (2020). An Investigation on Festival Perception and Satisfaction: The Case of Adana and Antalya Film Festival, Journal of Turkish Tourism Research, $4(4): 3855-3872$.

(C) 2020 Türk Turizm Araştırmaları Dergisi. 


\section{Gíriş}

Etkinlik turizmi son y1llarda özel ilgi turizmi çeşitleri arasında turizm endüstrisinin önemli ögelerinden biri haline gelerek turizm, seyahat, boş zaman ve konaklama endüstrilerine önemli bir katkı sağlamaktadır (Crompton ve McKay, 1997:429). Aynı zamanda toplumlar ve destinasyonlar için yarar sağlayarak çeşitli ekonomik, sosyal, çevresel hedeflere ulaşmada dikkat çeken bir araçtır. Destinasyonlar arasındaki rekabetin artması nedeniyle genellikle bir çekicilik unsuru olarak nitelendirilen etkinlikler, artık birçok yerleşim yerinde kimi zaman yerel, kimi zaman ulusal veya uluslararası düzeyde düzenlenmektedir.

Etkinlikler kültürel çeşitlilikleri sergilemek, yerleşim yerlerini tutundurmak, yerel halk için eğlence olanaklarını arttırmak, bölgeye ziyaretçi çekmek, yaşanılan yerdeki yaşam kalitesini geliştirmek ve gelir yaratmak amaçlarıyla düzenlenirler (Yolal, 2017:36). Etkinlikler düzenlendikleri bölge ya da destinasyona turist çekmenin yanısıra, toplumsal kimliğin korunmasına ve gelişmesine de yardımcı olmaktadırlar (Derret, 2004:39).

Turizm pazarlamasında kentlerin önemi gittikçe artmakta, bazı şehirler tek başına ait oldukları ülkeden daha fazla turist çekebilmektedir. Bu durum turizm tanıtımında şehirleri ön plana çıarmayı, şehirleri markalaştırmayı zorunlu hale getirmektedir (Bilgili vd., 2012:118). Festivaller açısından duruma bakıldığında günümüzde Cannes Film Festivali, Rio Karnavalı, Toronto, Berlin Film Festivali gerçekleştirildikleri destinasyonların markalaşmasında etkili etkinliklerdir. Diğer taraftan etkinliklere ev sahipliği yapılması yerel halk için de toplumsal faydalar sağlamaktadır. Etkinliklerin düzenlenmesiyle, ziyaretçiler ve yerel halkın bir araya gelmesi, birlikte eğlenmeleri ve böylece yerel halkın yaşam kalitesinin artmasına uygun bir ortam oluşturulmaktadır. Etkinliklere ilişkin gerek yerel halkın gerek yabancıların olumlu tutumları, etkinliklere yönelik desteği de etkileyecektir.

Türkiye farklı temalarda (müzik, kültür ve sanat, tarımsal ürünler vb.) festivaller organize ederek etkinlik turizmini geliştirmeye çalışan bir ülkedir. Ülkede gerçekleştirilen uluslararası film festivalleri (15 adet) hem sinema kültürünü yaygınlaştırılmakta hem de kentin sahip olduğu çekiciliklerin ön plana çıkarılmasında aracı olmaktadır. Hatta düzenlendikleri şehirlerle özdeşleşmiş durumdadır. Bu bakımdan Uluslararası Adana Film Festivali (1969) ve Antalya Uluslararası Altın Portakal Film Festivali (1964) en eski ve dikkat çekici film festivalleri olarak karşımıza çıkmaktadır. Adana'da düzenlenen film festivali Çukurova'nın geleneksel ürünü olan pamuğu simgelerken, Antalya'daki festival Antalya'nın portakalını simgelemektedir.

Araştırma ile ziyaretçilerin festival algılarının ne yönde olduğunun belirlenmesi ile festival memnuniyetini en üst düzeye çıkararak tekrar ziyaret etme oranlarını arttırmada, ilin tanitılmasında, ekonominin canlanmasında ve etkinlik turizmi potansiyelinin geliştirilmesinde katkı sağlaması hedeflenmektedir. Ayrıca araştırma ile tespit edilen eksiklik ve beklentilerin, etkinlik düzenleyiciler ve yerel yöneticilerle paylaşılmasıyla yeniden düzenlenecek olan festivallerde katkı sağlayacağı düşünülmektedir.

Bu bağlamda araştırmanın amacl, festival turizmi kapsamında Adana ve Antalya Film Festivali'ne katılan turistlerin festivali nasıl algıladıkları ve festivale yönelik memnuniyet düzeylerinin ne olduğunun belirlemesidir. Memnuniyet üzerinde etkili olan demografik değişkenlerin ve memnuniyeti en iyi yordayan festival algısı faktörlerinin neler olduğunun tespit edilmesi araştırmanın bir diğer amacını oluşturmaktadır.

\section{LITERATÜR TARAMASI}

Turistik destinasyonlar, bölgeler ya da şehirler alternatif turizm ürünü oluşturmak, özellikle düşük sezonda turist sayısını arttırmak, bölgenin turizmin sağladığı ekonomik faydalardan azami derecede yararlanmasını sağlamak, diğer destinasyonlar karşısında rekabet avantajı elde 
etmek gibi turizm amaçlarının dışında bölgeye istihdam yaratmak, şehrin altyapı iyileştirmelerinin gerçekleştirilmesi, yerel halkın refah seviyesinin arttırılması, sosyal kaynaşmanın sağlanması, bölgenin tanıtımını yaparak dikkat çekilmesi, kültür-sanat izleyici kitlesini genişletmek gibi çok çeşitli nedenlerle yerel, ulusal ya da uluslararası bazda düzenlenen etkinliklere yönelmektedir (Erdem vd., 2018:229). Bu etkinlikler, temalarına göre farklı türlere ayrılmaktadır. Bunlar, kültürel ve dinsel etkinlikler, toplumsal kutlamalar ya da festivaller, sanat ve eğlence etkinlikleri, spor etkinlikleri, iş amaçlı etkinlikler, eğitimsel ve bilimsel toplantılar, rekreasyonel etkinlikler, spor etkinlikleri, politik etkinlikler ve özel etkinliklerdir (Getz, 1997:7; Karagöz, 2006:16).

Etkinlikler, toplumun yeni deneyimler yaşamasına, yeni şeyler öğrenmesine, kültürel deneyimlere katılmasına ve yeni beceriler keşfetmesine imkan vermektedir. Ayrıca bireylerin etkinliğe katılan ulusal ve uluslararası düzeydeki sanatçılarla etkileşimde bulunmasına imkan tanımasının yanında bireyin yeni şeyleri deneyimlemesine, mutluluk hissi ve yaşadığı toplumun bir bireyi olmaktan dolayı gurur duymasına da etki etmektedir (Yolal, 2017: 38).

Bir destinasyonun turistik çekiciliğini canlandırmada ve geliştirmede etkili olan, otoritelerin bilgisi dahilinde belirli aralıklarla turist çekmek için yapılan etkinlik türlerinden birisi olan festivaller, "tatil" anlamina gelen Latince "festum/festa/festivas" kelimesinden türetilmiş, kutlama ya da şükran duygularını sunma amacıyla gerçekleştirilen sosyal bir toplanmayı ifade eder (Karaca vd., 2017:224; Cudny vd., 2012:708). Türk Dil Kurumu'na göre festival; belli bir sanat dalında oyun ve filmlerin sunulması, gösterilmesi, sonunda ödül, derece verilmesi biçiminde düzenlenen ulusal veya uluslararası gösteri dizisi, şenlik (örneğin Antalya film festivali) şeklinde tanımlanmaktadır (TDK, 2019).

Festivaller; boş zaman, sosyal ve kültürel deneyimler için eşsiz fırsatlardır ve genellikle toplumun ekonomik kalkınma amaçları için yaratılmaktadır. Gerek yerel halk gerekse festivali görmek için o bölgeyi ziyaret eden turistler farklı beklentiler içinde oldukları için festivallere katılım amacı farklılık göstermektedir. Bireylerin festivallere katılım amaçlarının; sosyalleşme, farklı kültürleri keşfetme, bir gruba ait olma güdüsünü gerçekleştirme ve güzel zaman geçirme gibi faktörler olduğu yapılan araştırmalarla bulgulanmıştır (Giritlioğlu vd., 2015:308). Buradan hareketle, tatmin olmuş festival katılımcılarının tekrar eden ziyaretçiler haline gelebileceği, ağızdan ağıza reklam etkisi ile yeni ziyaretçileri doğurup turizm gelirlerinde artışa sebep olabileceği söylenebilir (Cole ve Chancellor, 2009:323). Ayrıca festivale yönelik olumlu tutumların festival ve destinasyon imajı üzerinde etkili olduğu ve sadakat ile sonuçlandığı ayrı bir tespittir (Jawahar, Vincent ve Philip, 2020:11).

Dünya çapında düzenlenen festival ve özel etkinliklerin sayısının zamanla artış göstermesi konuyla ilgili araştırmaların sayısının da hızla artmasını sağlamıştır. Etkinlik turizmi alanında yapılan araştırmalar genellikle, festival ve özel etkinliklerin ekonomik etkileri (Gartner ve Holecek, 1983; Uysal ve Gitelson, 1994; Walo vd., 1996; Crompton ve McKay, 1997; Kim vd. 1998; Thrane, 2002) katılımcların motivasyonları ile katılım sebeplerinin (Uysal vd., 1991,1993; Mohr vd., 1993; Backman vd., 1995; Formica ve Uysal 1996; Schneider ve Backman 1996; Scott, 1995; Crompton ve McKay 1997; Formica ve Murrmann, 1998; Nicholson ve Pearce 2001;) ya da Blešić vd. 2013; Kruger ve Saayman, 2019; Carlos, 2019; Vinnicombe vd., 2017; Li vd., 2016) festival memnuniyeti (Wu ve Ai, 2016; Song vd., 2017; Velikova vd., 2017; Tanford ve Jung, 2017; Culha, 2020) ve festival sadakatinin (Lee, 2016; Girish ve Chen, 2017; Naqvi vd., 2018; Kruger, 2019; Kruger ve Viljoen, 2019; Dalgic ve Birdir, 2020) belirlenmesi üzerine yoğunlaşmıştır (Gürsoy vd., 2004:172).

Destinasyonlar arasındaki rekabet artışından dolayı festivaller için bilgi ihtiyacı, özellikle etkinlik katılımcılarının motivasyon analizi son derece önemli bir hale gelmiştir (Yolal vd., 2009:278). 
Gerçekten de turizmden yarar elde etmeye çalışan toplumlar, toplum odaklı festivallere ev sahipliği yaparak bu konularda farklılık yaratmaya çalışmaktadır (Delamere ve Hinch, 1994:27; Higham ve Ritchie, 2001:43). Özellikle düşük sezonda bilinçli bir şekilde gerçekleştirilen etkinlikler turizm sezonunu uzatmaya yardım edebilmektedir (Goldblatt, 2000:7). Bunun yanı sıra medyanın etkinliğe göstermiş olduğu ilgi de destinasyonun tanıtım ve tutundurma stratejilerine katkıda bulunarak destinasyona yapılacak ziyaretleri özendirmektedir (Jago vd., 2003:7).

\section{Uluslararası Adana Film Festivali ve Antalya Uluslararası Altın Portakal Film Festivali}

Adana, farklı temalarda festivaller ve karnavallar düzenleyerek ilin etkinlik turizmi potansiyelini geliştirmeye çalışan bir kenttir. Uluslararası Adana Film Festivali ilde düzenlenen etkinliklerden biridir. İlk kez 1969 yılında Altın Koza Film Şenliği adıyla Adana Belediyesi ve Adana Sinema Kulübü öncülüğünde gerçekleştirilmiştir. Belli aralıklarla birtakım sorunlar nedeniyle kesitlere uğramış olan festival 2005 yılından bu yana kesintisiz devam etmektedir. 2020 yılında 27.cisi düzenlenen festival, günümüzde Akdeniz Ülkeleri, ABD, Japonya gibi dünyanın pek çok ülkesinden filmi ve sinema profesyonellerini konuk eden bir sinema platformu haline gelmiştir. Festival her yıl yaklaşık 70 bin izleyiciye ulaşmaktadır (http://www.adanafilmfestivali.org.tr).

Antalya Altın Portakal Film Festivali, Avrupa ve Asya'nın en köklü film festivallerinden biri, Türkiye'nin ise en eski ve uzun soluklu film festivalidir. İlki 1964 yılında gerçekleştirilen festivalin 2020 yılında 57.cisi düzenlenmiştir. 1950'li yılların ortalarında, tarihi Aspendos Tiyatrosu'nda konserler ve tiyatrolarla başlayan Antalya Altın Portakal Film Festivali, 2005 yılından itibaren uluslararası platformda iddialı bir film festivali olma yolunda emin adımlarla ilerlemektedir (Ekin, 2011:86).

Antalya ve Adana illerinde düzenlenen bu festivaller her iki ilin kültürünün ve sanatının dünya çapında tanınması açısından çok önemli bir görev üstlenmektedirler. Ayrıca sadece kentin değil, Türkiye'nin de tanıtımı açısından önemli bir işlevi yerine getirmektedirler.

Literatürü toparlamak gerekirse, destinasyonlar arasında daha fazla turist çekebilmek için var olan rekabet nedeniyle festival gibi etkinliklerin düzenlenmesi ve geliştirilmesi oldukça önemli bir konu haline gelmiştir. Durumu turizm sektörü açısından değerlendirecek olursak güçlü bir kent imajı yaratabilmek için yerli ve/veya yabancı turistlerin ziyaret ettikleri yerlerden her açıdan memnun ayrılmalarını sağlamak gerekmektedir. Destinasyona çekilmesi planlanan ziyaretçileri, festivaller düzenleyerek teşvik etmek olasıdır. Özellikle destinasyonla ilgili olumsuz bir imaj söz konusu ise; medyatik ve ünlü kişilerin katılımı ile gerçekleştirilebilecek bir etkinlik, destinasyon imajını olumlu yöne çevirebilecektir. Bu noktada dünya çapında destinasyon imajında oldukça etkili olan etkinlik türlerinden birinin film festivalleri olduğu şüphesizdir.

\section{Araştırmanın Yöntemi}

\section{Evren ve Örneklem}

Araştırmanın evrenini Adana ve Antalya Film Festivallerine katılan bireylerin tamamı oluşturmaktadır. Festival alanları kompleks alanlar olduğu ve istatistiksel veriye ulaşma zorluğu nedeniyle her iki şehirde de sinema salonunda yer alan seyircilerin sayısı baz alınmıştır. Adana Film Festivali'nde 120.000, Antalya Film Festivali'nde ise 32.100 katılımcı sinema salonlarında yer almıştır (Adana Büyükşehir Belediyesi 2017; Antalya Büyükşehir Belediyesi 2017). Evren 
büyüklüğü 10.000 'in üzerinde olduğu için sinırsız evren örnekleme yöntemi formülüne başvurulmuştur. Formül, \%5 güven aralığında 384 katılımcıya ulaşmanın yeterli olduğunu göstermektedir (Ural ve Kılıç 2006).

Anketler öncelikle Adana'da 25 Eylül- 1 Ekim 2017 ve Antalya'da 21-27 Ekim 2017 tarihleri arasında festival alanında kolayda örnekleme tekniği ile araştırmacıların kendileri tarafından yüz yüze gerçekleştirilmiştir. Adana'da 356 ve Antalya'da 347 olmak üzere toplamda 701 kullanılabilir ankete ulaşılmıştır.

\section{Veri Toplama Aracı}

Araştırmada veri toplama aracı olarak nicel araştırma yöntemlerinden anket tekniği kullanılmıştır. Araştırmada Adana ve Antalya Film Festivali katılımcılarının festival algılarını ve memnuniyet düzeylerini belirlemek üzere Yıldırım, Karaca ve Çakıcı'nın (2016) "Yerel Halkın Adana-Uluslararası Portakal Çiçeği Karnavalı'na Yönelik Algı ve Memnuniyetleri" üzerine yapmış oldukları çalışmada kullandıkları 5 maddeli Likert tipi ölçekten yararlanılmıştır. Ölçek, $1=$ Kesinlikle katılmıyorum ve $5=$ Kesinlikle katılıyorum şeklinde derecelendirilmiştir.

\section{Verilerin Analizi}

Verilerin analizinde veri setinin faktör analizine uygun olup olmadığını test etmek üzere KMO ve Barlett Küresellik Testi'ne başvurulmuştur. Daha sonra festival katılımcılarının festival algılarının ve memnuniyetlerinin hangi faktörlerden oluştuğunu belirlemek üzere açımlayıcı faktör analizine başvurulmuştur. Buna ek olarak her iki festivalin katılımcılarının memnuniyet düzeyleri de regresyon analizine tabi tutulmuştur. Festival katılımcılarının memnuniyetleri üzerinde kategorik bağımsız değişkenlerden cinsiyet, medeni durum, eğitim durumu, yaş ve geliş sıklığının yordayıcılığını test etmek üzere lojistik regresyon analizinden yararlanılmıştır. Festival katılımcılarının memnuniyetlerini en iyi yordayan demografik değişkenleri ve festival algısı boyutlarını tespit etmek üzere CHAID Analizi'ne başvurulmuştur.

\section{BULGULAR}

Araştırmada festivale katılan turistlerin festival algısı değişken gruplarını belirlemek amacıyla açımlayıcı faktör analizi uygulanmıştır. Veri setinin faktör analizine uygun olup olmadığını tespit etmek amacıyla KMO ve Bartlett testi yapılmıştır. Çalışmanın bulgularına bakıldığında Tablo 1'de Kaiser-Meyer-Olkin örneklem büyüklüğü katsayısı 0,945 olarak hesaplanmıştır. Barlett testi 0,000 ile anlamlı olduğu görülmektedir (Büyüköztürk, 2012). Sonuçlar veri setinin faktör analizine uygun olduğunu göstermektedir. Faktör analizi sonucunda maddeler 4 faktör altında toplanmıştır. 14. ve 15. madde binişik madde olduğu için analizden çıkarılmış ve yeniden faktör analizi yapılmıştır. Sonuç olarak elde edilen dört faktör toplam varyansın \%61,641 'ini açıklamaktadır.

İlk faktör 6 maddeden oluşmaktadır. İçerdiği maddeler iletişim ve kültüre vurgu yaptığı için birinci faktör "Sosyal ve kültürrel yararlar" olarak isimlendirilmiştir. En yüksek faktör yüküne sahip olan madde ,799 ile "Festival yerel kültürün korunmasına yardımcı olmaktadır" iken en düşük faktör yüküne sahip olan madde, 596 ile "Festival yerel halkın sosyo-kültürel gelişimine katkı sağlamaktadır " şeklindedir. Birinci faktör aynı zamanda \%42.507 ile varyans açıklama gücü en yüksek olan faktördür. 
İkinci faktör 4 maddeden oluşmaktadır. Maddeler festivaldeki etkinliklere ve bu nedenle gelen turistlere odaklandığı için ikinci faktör "Turistik yararlar" olarak adlandırılmıştır. En yüksek faktör yüküne sahip olan madde ,794 ile " Festivalle ilgili yapılan tanıtımlar yeterli düzeydedir" iken en düşük faktör yüküne sahip olan madde ,625 ile "Festival kente gelen yerel turist sayısını arttırmaktadır" şeklindedir.

Üçüncü faktör 5 maddeden oluşmaktadır. Maddeler festivalden edinilen bireysel ve kentsel kazanımlara odaklandığı için üçüncü faktör "Bireysel ve kentsel yararlar" olarak adlandırılmıştır. En yüksek faktör yüküne sahip olan madde ,726 ile "Festival yörenin imajını olumlu etkilemektedir" iken en düşük faktör yüküne sahip olan madde ,487 ile "Festival günlük stresimi atmamı sağladı" şeklindedir.

Dördüncü faktör 5 maddeden oluşmaktadır. Maddeler festival sebebiyle artan satışlara ve olanaklara dayandığı için dördüncü faktör "Ekonomik yararlar" olarak adlandırılmıştır. En yüksek faktör yüküne sahip olan madde ,776 ile "Festival yerel işletmelerin iş hacmini arttırmaktadır" iken en düşük faktör yüküne sahip olan madde ,603 ile "Festival işletmeleri yeni aktiviteler oluşturma konusunda cesaretlendirmektedir" şeklindedir. Faktör analizi sonucu, Yıldırım, Karaca ve Çakıcı'nın (2013) yapmış oldukları faktör analizi sonuçlarıyla örtüşmektedir. Ancak bu araştırmada bireysel ve kentsel yararlar tek bir faktörde toplanmıştır. Festival algısı ölçeğine uygulanan faktör analizi Tablo 1'de yer almaktadır.

Tablo 1. Festival Algısı Ölçeğine Uygulanan Faktör Analizi

\begin{tabular}{|c|c|c|c|c|c|}
\hline Faktörler & Yükü & Özdeğeri & A.Varyans & Ort. & Alfa \\
\hline F1. SOSYAL ve KÜLTÜREL YARARLAR & & 8,501 & 42,507 & 3,458 & 870 \\
\hline $\begin{array}{l}\text { 1.Festival yerel halk ile katılımcıların } \\
\text { iletişim kurmasını sağlamaktadır. }\end{array}$ & ,661 & & & & \\
\hline 2.Festival ilin kültürünü yansıtmaktadır. & 741 & & & & \\
\hline $\begin{array}{l}\text { 3.Festival yörenin yaşam standartlarını } \\
\text { yükseltmesine yardımcı olmaktadır. }\end{array}$ & ,711 & & & & \\
\hline $\begin{array}{l}\text { 4. Festival yerel kültürün korunmasına } \\
\text { yardımcı olmaktadır. }\end{array}$ & ,799 & & & & \\
\hline $\begin{array}{l}\text { 5. Festival yerel halkın sosyo-kültürel } \\
\text { gelişimine katkı sağlamaktadır. }\end{array}$ &, 596 & & & & \\
\hline $\begin{array}{l}\text { 6. Yerel halkın tarihi ve kültürel değerlere } \\
\text { sahip çıktığı görülmektedir. }\end{array}$ & ,681 & & & & \\
\hline F2. TURISTIK YARARLAR & & 1,031 & 8,224 & 3,136 & ,785 \\
\hline $\begin{array}{l}\text { 8. Festivalde düzenlenen etkinlikler yeterli } \\
\text { düzeydedir. }\end{array}$ & ,743 & & & & \\
\hline $\begin{array}{l}\text { 9. Festivalle ilgili yapılan tanıtımlar yeterli } \\
\text { düzeydedir. }\end{array}$ & 794 & & & & \\
\hline $\begin{array}{l}\text { 10. Festival kente gelen yerli turist sayısını } \\
\text { arttırmaktadır. }\end{array}$ & ,625 & & & & \\
\hline $\begin{array}{l}\text { 11. Festival kente gelen yabancı turist } \\
\text { sayısını arttırmaktadır. }\end{array}$ & 645 & & & & \\
\hline $\begin{array}{l}\text { F3. BİREYSEL VE KENTSEL } \\
\text { YARARLAR }\end{array}$ & & 1,151 & 5,755 & 3,730 & ,735 \\
\hline $\begin{array}{l}\text { 7. Festival yerel halka sosyal etkileşim } \\
\text { fırsatları sağlamaktadır }\end{array}$ &, 573 & & & & \\
\hline
\end{tabular}




\begin{tabular}{|c|c|c|c|c|c|}
\hline $\begin{array}{l}\text { 12. Festival hoş ve eğlenceli vakit } \\
\text { geçirmemi sağladı. }\end{array}$ &, 550 & & & & \\
\hline $\begin{array}{l}\text { 13. Festival günlük stresimi atmamı } \\
\text { sağladı. }\end{array}$ & ,487 & & & & \\
\hline $\begin{array}{l}\text { 16. Festival yörenin imajını olumlu } \\
\text { etkilemektedir. }\end{array}$ & ,726 & & & & \\
\hline $\begin{array}{l}\text { 17. Festival yörenin tanıtımına katkı } \\
\text { sağlamaktadır. }\end{array}$ & ,701 & & & & \\
\hline F4. EKONOMIK YARARLAR & & 1,645 & 5,156 & 3,359 & 861 \\
\hline $\begin{array}{l}\text { 18. Festival yerel halka becerilerini } \\
\text { sergileme ve kazanç sağlama fırsatı } \\
\text { sağlar. }\end{array}$ & ,627 & & & & \\
\hline $\begin{array}{l}\text { 19. Festival şehir projelerine (altyapı, } \\
\text { üstyapı vb.) ekonomik kaynak } \\
\text { sağlamaktadır. }\end{array}$ & ,718 & & & & \\
\hline $\begin{array}{l}\text { 20. Festival yerel işletmelerin iş hacmini } \\
\text { arttırmaktadır. }\end{array}$ & ,776 & & & & \\
\hline $\begin{array}{l}\text { 21. Festival süresince daha çeşitli mal ve } \\
\text { hizmetler kentte satışa sunulmaktadır. }\end{array}$ & ,708 & & & & \\
\hline $\begin{array}{l}\text { 22. Festival işletmeleri yeni aktiviteler } \\
\text { oluşturma konusunda } \\
\text { cesaretlendirmektedir. }\end{array}$ & 603 & & & & \\
\hline \multicolumn{6}{|c|}{$\begin{array}{l}\text { Faktör çıkarma metodu: Temel bileşenler analizi; Döndürme metodu: Varimax; } \\
\text { Kaiser-Meyer-Olkin Örneklem Yeterliliği: \%93,5; Barttlet's Küresellik Testi için Ki-Kare: } \\
\text { 7894.608; s.d.:231; p<0.0001; } \\
\text { Açılanan toplam varyans: \%61,641; Ölçeğin tamamı için güvenirlik katsayısı: 0,927; Genel } \\
\text { ortalama: 3,420 } \\
\text { Tepki kategorileri= 1: Kesinlikle katılmıyorum, ..... 5:Kesinlikle katılıyorum }\end{array}$} \\
\hline
\end{tabular}

Memnuniyet ölçeğine uygulanan faktör analizi sonucunda maddelerin tek bir faktör altında karşımıza çıktığı görülmekte ve toplam varyansın \%73,766'sını açılamaktadır.

Tablo 2. Memnuniyet Ölçeğine Uygulanan Faktör Analizi

\begin{tabular}{|c|c|c|c|c|c|}
\hline & Yükü & Özdeğeri & A.Varyans & Ort. & Alfa \\
\hline $\begin{array}{l}\text { 23.Film Festivali'nin düzenlenmesinden } \\
\text { memnunum. }\end{array}$ & 802 & 3,688 & 73,766 & 3,864 & ,910 \\
\hline $\begin{array}{l}\text { 24.Film Festivaline gelmekle iyi bir karar } \\
\text { verdim. }\end{array}$ & 871 & & & & \\
\hline $\begin{array}{l}\text { 25.Film Festivali ile ilgili etrafıma olumlu } \\
\text { şeyler söyleyeceğim. }\end{array}$ & 877 & & & & \\
\hline $\begin{array}{l}\text { 26.Gelecek sene festivale yine gelmeyi } \\
\text { düşünüyorum. }\end{array}$ & ,882 & & & & \\
\hline $\begin{array}{l}\text { 27.Festivalden genel olarak memnun } \\
\text { kaldım. }\end{array}$ & ,860 & & & & \\
\hline \multicolumn{6}{|c|}{$\begin{array}{l}\text { Faktör çıkarma metodu: Temel bileşenler analizi; Döndürme metodu: Varimax; } \\
\text { Kaiser-Meyer-Olkin Örneklem Yeterliliği: \%869; Barttlet's Küresellik Testi için Ki-Kare: } \\
\text { 2350.829; s.d.:10; }<<0.0001 \text {; } \\
\text { Tenki kategorileri= } 1 \cdot \text { Kesinlikle katılmıvorum }\end{array}$} \\
\hline
\end{tabular}


Adana Film Festivali'ne katılan turistlerin festival algıları ile festival memnuniyetleri arasındaki ilişkiyi belirlemek üzere regresyon analizine başvurulmuştur. Analiz sonucunda festival memnuniyeti üzerinde sosyal ve kültürel yararlar ile bireysel ve kentsel yararlardan oluşan iki faktörün etkili olduğu saptanmıştır. Sosyal ve kültürel yararlardaki bir birimlik artış memnuniyet üzerinde 0,320'lik bir artışa neden olurken; bireysel ve kentsel yararlardaki bir birimlik artış memnuniyet üzerinde 0,353'lük bir artış meydana getirmektedir. Adana Film Festivali katılımcılarının memnuniyetleri üzerinde etkili olan festival algısı boyutları Tablo 3'te yer almaktadır.

Tablo 3. Adana Film Festivali Katılımcılarının Memnuniyetleri Üzerinde Etkili Olan Festival Algısı Boyutları

\begin{tabular}{|l|l|l|l|l|c|l|l|}
\hline & \multicolumn{2}{|l|}{$\begin{array}{l}\text { Standardize } \\
\text { edilmemiş } \\
\text { katsayılar }\end{array}$} & $\begin{array}{l}\text { Standardize } \\
\text { edilmiş } \\
\text { katsayılar }\end{array}$ & $\begin{array}{l}\text { t- } \\
\text { değeri }\end{array}$ & Anlam düzeyi & Tolerans & VİF \\
\hline & B & $\begin{array}{l}\text { S. } \\
\text { Hata }\end{array}$ & Beta & & & & \\
\hline (Sabit) &, 358 &, 172 & & 2,085 &, 038 & & \\
\hline $\begin{array}{l}\text { Sosyal ve } \\
\text { kültürel } \\
\text { yararlar }\end{array}$ &, 355 &, 052 &, 320 & 6,765 &, 000 &, 512 & 1,955 \\
\hline $\begin{array}{l}\text { Bireysel ve } \\
\text { kentsel } \\
\text { yararlar }\end{array}$ &, 346 &, 048 &, 353 & 7,241 &, 000 &, 482 & 2,073 \\
\hline $\begin{array}{l}\text { Bağ1mlı değişken: Festival memnuniyeti; R: 0,775; R2: \%60; } \\
\text { Düzeltilmiş R2: \%59,6; F: } 130,975 ; p<0,001\end{array}$ & & & & & \\
\hline
\end{tabular}

Antalya Film Festivali'ne katılan turistlerin festival algıları ile festival memnuniyetleri arasındaki ilişkiyi belirlemeye yönelik regresyon analizine başvurulmuştur. Analiz sonucunda festival memnuniyeti üzerinde yalnızca bireysel ve kentsel yararlar faktörünün etkili olduğu saptanmıştır. Bireysel ve kentsel yararlardaki bir birimlik artış memnuniyet üzerinde 0,620'lik bir artış meydana getirmektedir. Adana Film Festivali'nde memnuniyet üzerinde etkili olan sosyal ve kültürel yararlar faktörü Antalya Film Festivali katılımcılarının memnuniyetleri üzerinde etkili olamamıştır. Her iki festivalde de memnuniyet üzerinde etkili olan faktör bireysel ve kentsel yararlar olarak karşımıza çıkmaktadır. Antalya Film Festivali katılımcılarının memnuniyetleri üzerinde etkili olan festival algısı boyutları Tablo 4 'te yer almaktadır.

Tablo 4. Antalya Film Festivali Memnuniyeti Üzerinde Etkili Olan Festival Algısı Boyutları

\begin{tabular}{|c|c|c|c|c|c|c|c|}
\hline & \multicolumn{2}{|c|}{$\begin{array}{l}\text { Standardize } \\
\text { edilmemiş } \\
\text { katsayılar }\end{array}$} & $\begin{array}{l}\text { Standardize edilmiş } \\
\text { katsayılar }\end{array}$ & $\begin{array}{l}\text { t- } \\
\text { değeri }\end{array}$ & $\begin{array}{l}\text { Anlam } \\
\text { düzeyi }\end{array}$ & Tolerans & VİF \\
\hline & B & $\begin{array}{l}\text { S. } \\
\text { Hata }\end{array}$ & Beta & & & & \\
\hline (Sabit) & ,553 & 157 & & 3,520 & ,000 & & \\
\hline $\begin{array}{l}\text { Bireysel ve } \\
\text { kentsel } \\
\text { yararlar }\end{array}$ & 692 & ,056 & 620 & 12,318 & ,000 & 481 & 2,080 \\
\hline
\end{tabular}


Festival katılımclarının memnuniyetleri üzerinde kategorik bağımsız değişkenlerden cinsiyet, medeni durum, eğitim durumu, yaş ve festivale geliş sıklığının yordayıcılığını test etmek üzere lojistik regresyon analizinden yararlanılmıştır. Tablo 5 incelendiğinde 318 katılımcının kadın, 351 katılımcının erkek olduğu; 228 katılımcının evli, 441 katılımcının evli olmadığı; 169 katılımcının lise ve altı, 500 katılımcının lisans ve lisans üstü eğitim düzeyinde olduğu; 381 katılımcının 33 yaşından kü̧̈ük, 288 katılımcının 33 yaşından büyük olduğu; 261 katılımcının festivalde 3 günden az bulunduğu ve 408 katılımcının 4 ile 7 gün arasında festivale katıldığı görülmektedir. Festivalden memnun olarak ayrılan 395, memnun olmadan ayrılan 274 katılımcı bulunmaktadır.

Lojistik regresyona yönelik istatistiksel değerler incelendiğinde, Ki-kare değeri 8 serbestlik dereceli 8,534'tür. Doğru sinıflandırma yüzdesi \%61,7'dir. Uyum iyiliği test sonucu 0,001'dir. Bu değer 0.05 ten küçük olduğu için yüksek derecede anlamlı bir model olduğu söylenilebilir (Uğurlu, 2016). Bağımlı değişken olan genel memnuniyet düzeyinde meydana gelen değişimlerin $\% 2,9$ ile \%4'ü arasındaki kısmın bağımsız değişkenlerle açıklandığını tespit edilmiştir. Hosmer ve Lemeshow testi, 383 ile 0,05 'ten büyüktür. Bu da modelin desteklendiğini göstermektedir (Uğurlu, 2016). Yordayıcı değişkenin etkisini görmek için Block 0'daki sınıflandırma tablosuyla kıyaslandığında $\% 59$ olan sinıflandırmanın \%61,7 olduğu görülmektedir. Block sınıflandırmadaki değerin üzerinde bir gelişme olduğu görülmektedir. Pozitif yordayıcı değer $\% 62,3$ iken negatif yordayıcı değer $\% 58,6$ dır. Pozitif yordayıcı değer modelin, gözlenen bireylere sahip olma yüzdesidir. Festival katılımclarının memnuniyetleri üzerinde demografik değişkenlerden yalnızca yaş $(, 000)$ ve medeni durum $(, 000)$ manidar bir katkı sağlamıştır. Cinsiyet, eğitim durumu ve festivale geliş sıklığı modele manidar bir katkı sağlayamamıştır. Yaşın ve medeni durumun ne yönde memnuniyet üzerinde yordayıcı olduğunu belirlemek için $B$ değerine bakılmaktadır. $B$ değeri yaş ve medeni durumun her ikisi için de negatiftir. Bu durumda katılımcıların yaşlarının 33'ten küçük olduğu ve evli olmadıkları durumlarda yaşın ve medeni durumun memnuniyeti yordama gücü daha yüksek olacaktır. Lojistik regresyon analizine yönelik bulgular Tablo 5'te yer almaktadır.

Tablo 5. Lojistik Regresyon Analizine Yönelik Bulgular

\begin{tabular}{|c|c|c|c|}
\hline \multicolumn{2}{|l|}{ Bağımsız Değişkenler } & Frekans & Bulgular \\
\hline \multirow[t]{2}{*}{ Cinsiyet } & Kadın & 318 & $\begin{array}{l}\text { Block } 0 \text { için sınıflandırma yüzdesi: } \\
59\end{array}$ \\
\hline & Erkek & 351 & $\begin{array}{l}\text { Block } 1 \text { için sınıflandırma yüzdesi: } \\
61,7\end{array}$ \\
\hline \multirow[t]{2}{*}{ Medeni durum } & Evli olanlar & 228 & $\begin{array}{lll}\text { Pozitif } \quad \text { yordayıc1 } & \text { değer: } \\
352 / 565 \times 100=62,3 & \end{array}$ \\
\hline & Evli olmayanlar & 441 & $\begin{array}{l}\text { Negatif yordayıc1 değer: } \\
61 / 104 \times 100=58,6\end{array}$ \\
\hline \multirow[t]{2}{*}{ Eğitim durumu } & Lise ve altı & 169 & Uyum iyiliği test sonucu: 0,001 \\
\hline & $\begin{array}{l}\text { Lisans ve lisans } \\
\text { üstü }\end{array}$ & 500 & Hosmer ve Lemeshow testi: ,383 \\
\hline \multirow[t]{2}{*}{ Yaş } & 33 ve alt1 & 381 & Yaş:Exp(B): , 453 \\
\hline & 33 yaş üzeri & 288 & Medeni durum: $\operatorname{Exp}(B):, 471$ \\
\hline \multirow[t]{2}{*}{ Festivale geliş sıklığı } & 3 gün ve altı & 261 & df:8 \\
\hline & 4-7 gün arası & 408 & Ki-kare: 8,534 \\
\hline
\end{tabular}

Lojistik regresyon analizi sonucunda memnuniyeti yordayan demografik değişkenlerden yaş ve medeni durumuna yönelik kapsamlı bilgilere ulaşmak adına CHAID Analizine başvurulmuştur. 
Analiz sonucunda memnuniyeti en iyi yordayan demografik değişkenin "yaş" olduğu bulgulanmıştır. Yaşı 33 ve altında olan katılımcıların \%62,7'sinin; yaşı 33'ün üstünde olanların ise \%54,1'inin genel memnuniyet düzeyi yüksektir. Yaşı 33'ün üstünde olan katılımcıların memnuniyetlerini yordayan ve ağacın ikinci dalını oluşturan değişken ise medeni durumdur. Evli olmayanların \%40,4'ünün; evli olanların ise \%61,5'inin genel memnuniyet düzeyi yüksektir. Sonuçlar lojistik resgresyon analizini desteklemektedir. Ek olarak yaşı 33 ve altında olanlar ile, 33 yaşından büyük olanlar içerisinde de evli olanların genel memnuniyet düzeylerinin diğerlerine göre daha yüksek olduğu görülmektedir. Memnuniyeti yordayan demografik değişkenlere CHAID Analizi aracılığıyla ulaşılan veriler Şekil 1'de yer almaktadır.

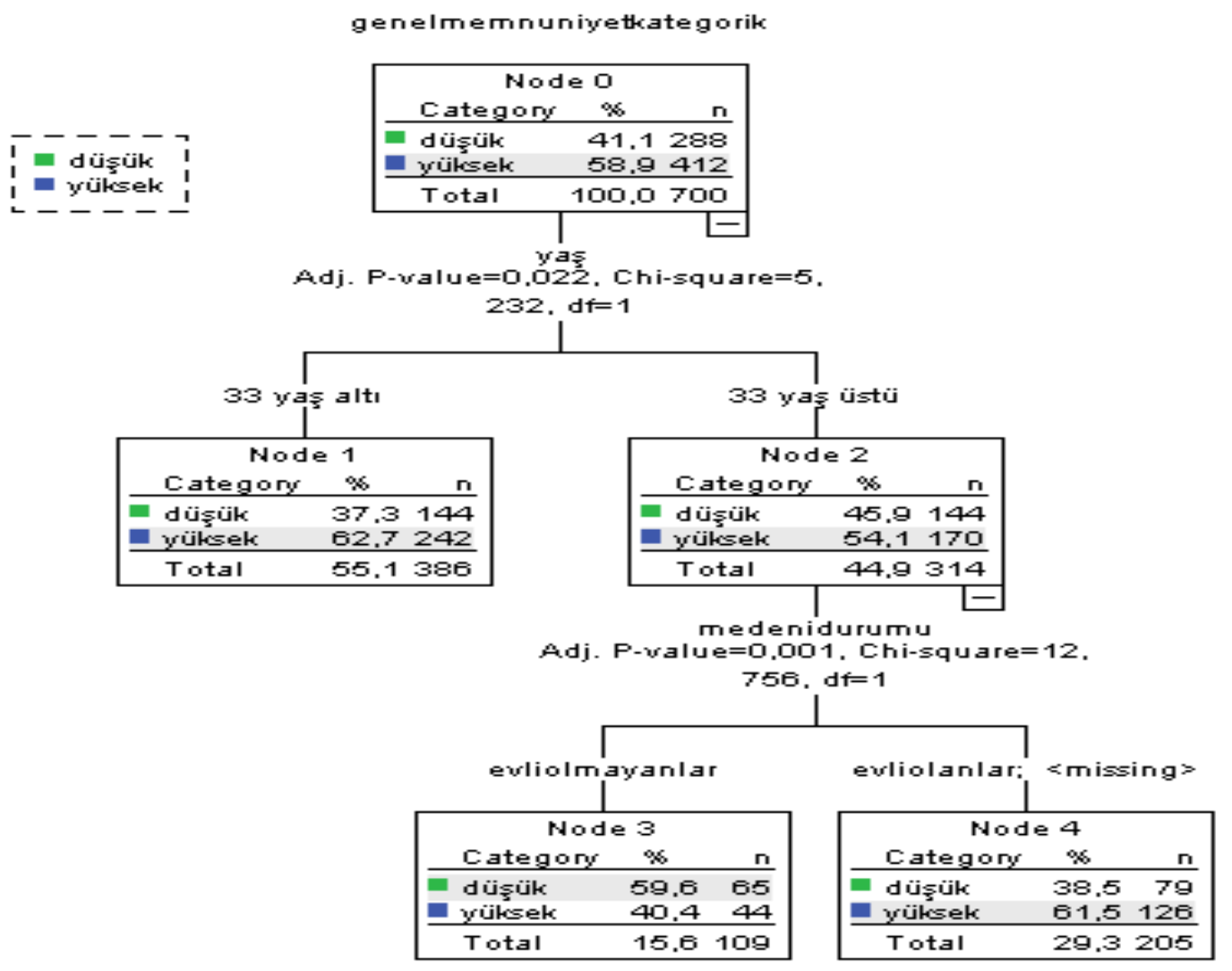

Şekil 1. Memnuniyeti Yordayan Demografik Değişkenlerin CHAID Analizi

Festival katılımcılarının genel memnuniyet düzeylerini en iyi yordayan festival algısı boyutlarını belirlemek üzere CHAID (Otomatik Ki-Kare Etkileşim Belirleme Analizi) Analizi'ne başvurulmuştur. CHAID Analizi, kategorik bağımlı değişkeni en çok yordayan bağımsız değişkenleri belirleyen, değişkenlerini sınıflandıran bir yöntemdir (Aksu ve Karaman, 2016). Tablo 6 incelendiğinde 700 kişiden oluşan katılımcıların \%58,9'u festivalden genel olarak memnun olarak ayrılmıştır. Festival memnuniyetini en iyi yordayan ve ağacın ilk dallanmasını oluşturan değişken bireysel ve kentsel yararlar faktörüdür. Bireysel ve kentsel yararlara ortalamanın üstünde puan vermiş olan katılımcları en iyi yordayan ve ağacın ikinci dallanmasını oluşturan değişken sosyal ve kültürel yararlardır. Sosyal ve kültürel yararlara yüksek puan vermiş olan katılımcıların memnuniyetlerini yordayan en iyi üçüncü değişken turistik yararlar olurken ekonomik yararlar memnuniyeti yordayan dördüncü ve sonuncu faktör olmuştur. Bireysel ve kentsel yararlara ortalamanın altında puan vermiş olan katılımcıları en iyi yordayan 
ve ağacın ikinci dallanması oluşturan değişken ekonomik yararlardır. Bu bağlamda bireysel ve kentsel yararlar aracılığıyla genel memnuniyet düzeyi yüksek olan katılımciların memnun olmalarında etkili olan ikinci faktör sosyal ve kültürel yararlar iken, bireysel ve kentsel yararların memnuniyete aracılık etmediği durumda ekonomik yararların ön plana çıktı̆̆ı görülmektedir. CHAID Analizi'ne yönelik bulgular Şekil 2'de gösterilmektedir.

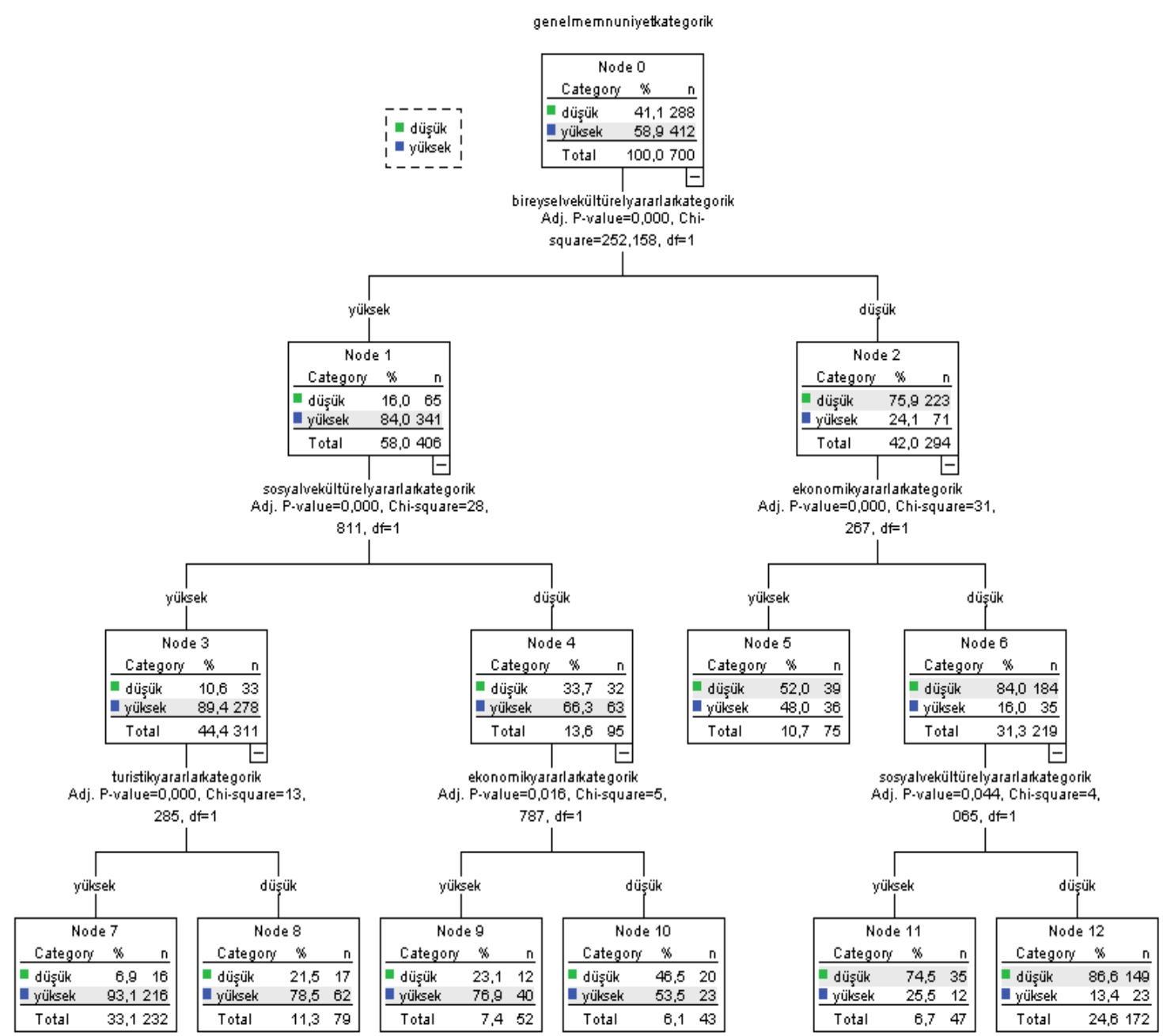

Şekil 2. Memnuniyeti Yordayan Festival Algısı Boyutlarının CHAID Analizi

\section{TARTIŞMA, SONUÇ ve ÖNERILER}

Bu çalışma Adana ve Antalya'da düzenlenen Uluslararası Film Festivali'ne ilişkin katılımcıların festival algıları ve festivalden memnuniyet düzeylerinin tespit edilmesi amaciyla planlanıp yürütülmüştür. Festivaller, bir yöreye olan ziyaretçi sayısını arttırmakta, yöre ve dolayısıyla ülke ekonomisinin getirisini arttırmakta ve yöre imajını güçlendirmektedir. Araştırmanın başlıca bulgularında katılımciların yarısından fazlasının festivalden memnun ayrıldığı ve her iki festivalin de yöreye bireysel ve kentsel yararlar sağladığıdır. Gürsoy, Kim ve Uysal'ın (2004) festivallerin algılanan etkileri üzerine yapmış oldukları çalışmada, festival düzenleyicilerin ekonomik yararlar yerine bireysel ve toplumsal yararlara odaklanmanın bireysel doyum 
üzerindeki öneminden bahsetmişlerdir. Çalışma bu yönüyle literatürdeki bulguları desteklemektedir.

Çalışmada dikkat çeken diğer bir bulgu da Uluslararası Adana Film Festivali katılımcılarının memnuniyet düzeylerini en çok yordayan değişkenin sosyal ve kültürel yararlar olduğudur. Yapılan birçok çalışmada (Chang, 2006; Dredge ve Whitford, 2011; Giritlioğlu vd., 2015) festivaller aracılığıyla farklı kültüre ve yapıya sahip birçok yerli/yabancı turistin bir araya gelmesi ve yöre halkı ile etkileşime geçmesi neticesinde yerel halk üzerinde önemli sosyal etkiler meydana geldiği ifade edilmektedir.

Katılımcıların memnuniyet düzeylerinde etkisi olmayan boyutların ise ekonomik ve turistik boyutlar olduğu görülmüştür. Bu durumla katılımcıların festivallerden bireysel ve kentsel olarak fayda sağladığı durumda memnun oldukları söylenebilir. Bu sonuçtan hareketle, yerel yönetimlerin ve festival düzenleyicilerin bu tarz etkinlikler düzenlerken bireysel, sosyal ve kentsel yararlara odaklanmaları gerektiğini söylemek mümkündür. Ayrıca filmler ve festivallerin yalnızca festival programı boyunca konuşulmadığı, etkilerinin uzun süre devam ettiği unutulmamalıdır (Uğurlu ve Uğurlu, 2011). Bu durum, katılımcıların festivale yönelik memnuniyet ve şikayetlerini yakınlarıyla paylaşmasıyla tamamlanmaktadır. $\mathrm{Bu}$ nedenle festivalin sürdürülebilirliğinin sağlanabilmesi için yerel yönetimler, katılımcıların festivalden memnun olarak ayrılmalarını önemsemelidir ve bu konuda etkili olan unsurları göz önünde bulundurulması gerekmektedir.

Araştırmada katılımcıların memnuniyet düzeylerinin demografik değişkenler açısından farklılık gösterip göstermediği CHAID analizi ile tespit edilmiştir. Bu analiz neticesinde 33 yaş altı bireylerin ve $33^{\prime}$ ten büyük olanlarda ise evli olan bireylerin genel memnuniyet düzeylerinin yüksek olduğu tespit edilmiştir. Tayfun ve Arslan'ın (2013:191) Ankara Alışveriş Festivali üzerine yapmış oldukları çalışmada da 20 yaş altı grubun diğer yaş gruplarına göre festivalden daha fazla memnun oldukları sonucuna ulaşılmıştır. Yolal ve diğerlerinin (2019:80) Eskişehir Film Festivali üzerine yapmış oldukları çalışmada ise genç kadın katılımcıların motivasyonları yüksek bulunurken görece yaşlı ve evli insanların sadece beraberlik boyutunda yüksek motivasyona sahip oldukları tespit edilmiştir. Bu bulgulardan hareketle bir başka çalışmada katılımcıların sosyal durumlarına göre festivalden beklenti düzeylerinin tespiti sağlanırsa gerçekleştirilecek olan yeni etkinliklerde nelere dikkat edilmesi gerektiği saptanabilir.

Araştırmada festival alanının talebi karşılamadaki yetersizliği nedeniyle her filme yer bulunamaması, festival alanı dışında diğer sinemalarda gösterilen filmlerde de ambiyansın yakalanamadığı tespit edilmiştir. Bu nedenle festival alan seçiminde daha çok ziyaretçinin katılımını sağlayacak yerlerin seçilmesi ya da var olan alanların yeniden yapılandırılması yerel yönetimlere ve festival düzenleyicilerine, önerilmektedir. Benzer şekilde Culha'nın (2020:19) Didim Zeytin Festivali katılımcıları üzerine yapmış olduğu çalışmasında festival deneyimi içerisinde estetik deneyimin önde gelen unsur olduğu, ayrıca festival ve hizmet ortamının festival ambiyansını etkileyen unsurlar olduğu ortaya çıkmıştır. Aşan ve diğerlerinin (2020:262) Sinop'ta gerçekleştirilen "Kuzey Fest" adlı müzik festivali katılımcıları üzerinde yapmış oldukları çalışmada ise yine festivalin estetik deneyimi vurgulanmıştır. Bu çalışmalardan hareketle festival katılımcllarının memnuniyetleri üzerinde estetik deneyimin önemli olduğu söylenebilir. Bu amaçla Adana ve Antalya Film Festivali katılımcılarının kendilerini eşsiz bir deneyimin içinde bulmaları amacıyla festivalin fiziksel çevresinin beklentiler ile uyumlu olması genel festival memnuniyeti üzerinde etkili olabileceği şüphesizdir. Ayrıca festivaller hatırlanabilir turizm deneyimi yarattı̆̆ için destinasyonların rekabet edebilirlikleri üzerinde de önemli bir rol oynamaktadır (Mainolfi ve Marino, 2018:2). Bu sebeple katılımcıların memnuniyet düzeyi arttıkça deneyimin hatırlanabilirliği de artacaktır. İleriki yapılacak olan çalışmalarda 
katılımcıların festival memnuniyetleri yanısıra festival deneyiminin hatırlanabilirliği ve bu durumun festivali yeniden ziyaret etme eğilimine etkisi araştırılabilir.

Etkinlik turizmi kapsamında gerçekleştirilen festival organizasyonlarında festivale katılan yerel halk kadar festivalin başından sonuna kadar alanda bulunan profesyoneller (jüri üyesi, film eleştirmeni, yönetmen, oyuncu, sinema emekçisi, blogger, influencer vb.) de unutulmamalıdır. Digital iletişim çağının günümüzdeki etkileri düşünüldüğünde, bu nitelikteki katılımcılar sosyal medya aracılığıyla birçok kitleye ulaşabilmekte ve gerçekleştirilen etkinliğin medya ve toplumdaki algısını etkileyebilmektedirler. Medyada festivalin benzersiz olduğu temaların vurgulanması festivali çekici hale getirmektedir ( $\mathrm{Li}$ ve diğerleri, 2020:11). Bu nedenle festival düzenleyiciler, profesyonellerin de festivalden memnun olarak ayrılmalarını sağlayacak tedbirler almalıdırlar. Ayrıca Baez-Montenegro ve Devesa-Fernandez'in (2017:188) Valdivia Uluslararası Film Festivali katılımcıları üzerinde yürütmüş oldukları araştırmada katılımcı memnuniyetinin sadakat üzerinde oldukça etkili olduğu bulgulanmıştır. Buradan hareketle festival süresince çeşitli etkinlikler düzenlenerek, yeme-içme olanakları zenginleştirilerek katılımcıların memnuniyet düzeyleri daha da arttırılabilir ve festivalin daha etkin tamamlanması sağlanabilir. Ayrıca bu çalışma kapsamında sadece festival alanını ziyaret eden katılımcılara yer verilmiştir. İleriki çalışmalarda festivallere katılan profesyonelleri kapsayan çalışmalar yapılabilir.

$\mathrm{Bu}$ araştırmadan sonra yapılacak araştırmalar için film festivallerinin farklı tarihlerde farklı örneklem gruplarında farklılık gösterip göstermediğini test etmek için boylamsal bir araştırma yapilabilir.

Son olarak, bu çalışmada anket yöntemi ile veri toplanmıştır. Konuyla ilgili ilerde yapılacak araştırmalarda, anket yöntemi yanısıra gözlem ve görüşme tekniği gibi nitel yöntemlerle de verilerin toplanması yararlı olabilecektir. Hatta her iki yöntemin kullanıldığı çalışmalar sayesinde daha derinlemesine ve daha fazla veri elde edilmesi mümkün olabilecektir.

\section{KAYNAKÇA}

Aksu, G. ve Karaman, H. (2016). CHAID Analizi. C.O. Güzeller (Editör.), Herkes İçin Çok Değişkenli İstatistik içinde (ss. 251-273) Ankara: Maya Akademi.

Aşan, K., Kaptangil, K., and Kınay, A. G. (2020). Mediating Role of Perceived Festival Value in the Relationship Between Experiences and Satisfaction, International Journal of Event and Festival Management, 11(2): 255-271.

Backman, K. F., Backman, S. J., Uysal, M., and Sunshine, K. M. (1995). Event Tourism: An Examination of Motivations and Activities, Festival Management and Event Tourism, 3(1): 15-24.

Báez-Montenegro, A., and Devesa-Fernández, M. (2017). Motivation, Satisfaction and Loyalty in the Case of a Film Festival: Differences Between Local and Non-Local Participants, Journal of Cultural Economics, 41(2): 173-195.

Bilgili, B., Yağmur, Ö. ve Yazarkan, H. (2012). Turistik Ürün Olarak Festivallerin Etkinlik ve Verimliliği Üzerine Bir Araştırma (Erzurum-Oltu Kırdağ Festivali Örneği), International Journal of Social and Economic Sciences, 2(2): 117-124.

Blešić, I., Pivac, T., Stamenković, I., and Besermenji, S. (2013). Motives of Visits to Ethno Music Festivals with Regard to Gender and Age Structure of Visitors, Event Management, 17(2): 145-154.

Chang, J. (2006). Segmenting Tourists to Aboriginal Cultural Festivals: An Example in the Rukai Tribal Area, Taiwan, Tourism Management, 27(6): 1224-1234. 
Cole, S. T., and Chancellor, H. C. (2009). Examining the Festival Attributes That Impact Visitor Experience, Satisfaction and Re-Visits Intention, Journal of Vacation Marketing, 15(4): 323-333.

Crompton, J. L., and McKay, S.L. (1997). Motives of Visitors Attending Festival Events, Annals of Tourism Research, 24(2): 425-439.

Cudny, W., Korec, P., and Rouba, R. (2012). Resident's Perception of Festivals-A Case Study of Lodz, Sociologia, 44(6): 704-728.

Culha, O. (2020). The Effect of Food Festival Quality on Place Attachment and Destination Recommendation Intention Through Festival Experience and Festival Satisfaction: The Case of the Didim International Olive Festival, Journal of Convention and Event Tourism, 21(4): 1-30.

Dalgıç, A. and Birdir, K. (2020). The Effect of Key Success Factors on Loyalty of Festival Visitors: The Mediating Effect of Festival Experience and Festival Image, Tourism and Management Studies, 16(1): 28-38.

Delamere, T. A., and Hinch, T. (1994). Community Festivals: Celebration or Sellout?, Recreation Canada, 52(1): 26-29.

Derrett, R. (2004). Festivals, Events and The Destination, In Yeoman I., Robertson M., Ali-Knight J., Drummond S., and McMahon-Beattie U. (Ed.), Festival and Events Management: An International Arts and Culture Perspective, (pp.32-64) Oxford: Elsevier Butterworth Heinemann.

Dredge, D. and Whitford, M. (2011). Event Tourism Governance and The Public Sphere, Journal of Sustainable Tourism, 19(4-5): 479-499.

Ekin, Y. (2011). Etkinlik Turizmi Kapsammnda Festivaller ve Antalya Altın Portakal Film Festivali'nin Yerel Halk Üzerindeki Sosyal Etkileri Konulu Bir Araştırma, Yayınlanmamış Doktora Tezi, Akdeniz Üniversitesi, Antalya.

Erdem, Ö., Mızrak, M., ve Aratoğlu, C. (2018). Festivallerin Bölge Turizmine Katkıları ve Sürdürülebilirliği: Uluslararası Mengen Aşçılık ve Turizm Festivali Örneği, Journal of Tourism and Gastronomy Studies, 6(1): 228-245.

Formica, S., and Murrmann, S. (1998). The Effects of Group Membership and Motivation on Attendance: An International Festival Case, Tourism Analysis, 3(3/4), 197-207.

Formica, S., and Uysal, M. (1995). A Market Segmentation of Festival Visitors: Umbria Jazz Festival in Italy, Festival Management and Event Tourism, 3(4), 175-182.

Gartner, W. C., and Holecek, D. F. (1983). Economic Impact of An Annual Tourism Industry Exposition, Annals of Tourism Research, 10(2): 199-212.

Getz, D. (1997). Event Management and Event Tourism. New York: Van Nostrand Reinhold.

Giritlioğlu, İ. Olcay, A. ve Özekici, Y.K. (2015). Bir Turizm Çeşitliliği Olarak Festival Etkinliklerinin Sınıflandırılması: Türkiye Üzerine Bir Değerlendirme, Sosyal Bilimler Araştırmaları Dergisi, 13: 306-323.

Girish, V. G. and Chen, C. F. (2017). Authenticity, Experience and Loyalty in the Festival Context: Evidence from the San Fermin Festival, Spain, Current Issues in Tourism, 20(15). 1551-1556.

Goldblatt, J. (2000). A Future for Event Management: The Analysis of Major Trends Impacting the Emerging Profession. In Allen J., Harris R., Jago L. and Veal A. J. (Ed.), Events Beyond 2000: Setting the Agenda, Proceedings of Conference on Event Evaluation, Research and Education, Australian Centre for Event Management, School of Leisure, Sport and Tourism (pp. 1-9) Sydney: University of Technology. 
Gürsoy, D., Kim, K., and Uysal M. (2004). Perceived Impacts of Festivals and Special Events by Organizers: An Extension and Validation, Tourism Management, 25: 171-181.

Higham J. E. S., and Ritchie B. (2001). The Evolution of Festivals and Other Events in Rural Southern New Zealand, Event Management, 7(1): 39-49.

Jago L., Chalip L., Brown G., Mules T., and Ali S. (2003). Building Events into Destination Branding: Insights from Experts, Event Management, 8(1): 3-14.

Jawahar, D., Vincent, V. Z., and Philip, A. V. (2020). Art-Event Image in City Brand Equity: Mediating Role of City Brand Attachment, International Journal of Tourism Cities, 6(3): 1-19.

Karaca, O. B., Yıldırım, O., ve Çakıcı, C. (2017). Adana Uluslararası Portakal Çiçeği Karnavalına Katılan Ziyaretçilerin Algı ve Memnuniyeti, Mustafa Kemal Üniversitesi Sosyal Bilimler Enstitüsü Dergisi, 14(37): 222-239.

Karagöz D. (2006). Etkinlik Turizmi ve Etkinlik Turizmi Bağlamında Yabancı Ziyaretçi Harcamalarının Ekonomiye Etkisi: Formula 12005 Türkiye Grand Prix Örneği, Yayınlanmamış Yüksek Lisans Tezi, Anadolu Üniversitesi, Eskişehir.

Kim, C., Scott, D., Thigpen, J. F., and Kim, S. S. (1998). Economic Impact of a Birding Festival, Festival Management and Event Tourism, 5(1-2): 51-58.

Kruger, M. (2019). Festival Loyalty to a South African Literary Arts Festival: Action Speaks Louder than Words!, International Journal of Event and Festival Management, 10(2): 189-206.

Kruger, M. and Saayman, M. (2019). All That Jazz: The Relationship Between Music Festival Visitors' Motives and Behavioural Intentions, Current Issues in Tourism, 22(19): 2399-2414.

Kruger, M., and Viljoen, A. (2019). Terroir Wine Festival Visitors: Uncorking the Origin of Behavioural Intentions, Current Issues in Tourism, 1-21. Doi: 10.1080/13683500.2019.1667310

Lee, Y. K. (2016). Impact of Government Policy and Environment Quality on Visitor Loyalty to Taiwan Music Festivals: Moderating Effects of Revisit Reason and Occupation Type, Tourism Management, 53: 187-196.

Li, H., Lien, C. H., Wang, S. W., Wang, T., and Dong, W. (2020). Event and City Image: The Effect on Revisit Intention, Tourism Review, 75. Doi: 10.1108/TR-10-2019-0419

Li, Y. N. and Wood, E. H. (2016). Music Festival Motivation in China: Free the Mind, Leisure Studies, 35(3): 332-351.

Mainolfi, G., and Marino, V. (2018). Destination Beliefs, Event Satisfaction and Post-Visit Product Receptivity in Event Marketing. Results from a Tourism Experience, Journal of Business Research, 116: 699-710.

Mohr, K., Backman, K. F., Gahan, L. W., and Backman, S. J. (1993). An Investigation of Festival Motivations and Event Satisfaction by Visitor Type, Festival Management and Event Tourism, 1(3): 89-97.

Monterrubio, C. (2019). Exploring Nudist Festival Attendance at a Mexican Beach: A Tourist Motivation Approach, Journal of Travel and Tourism Marketing, 36(5): 583-594.

Naqvi, M. H. A., Jiang, Y., Naqvi, M. H., Miao, M., Liang, C., and Mehmood, S. (2018). The Effect of Cultural Heritage Tourism on Tourist Word of Mouth: The Case f Lok Versa Festival, Pakistan, Sustainability, 10(7): 2391. 
Nicholson, R. E., and Pearce, D. G. (2001). Why Do People Attend Events: A Comparative Analysis of Visitor Motivations at Four South Island Events, Journal of Travel Research, 39(4): 449460.

Polat, S., Polat, S. A., ve Halis, M. (2013). Kent Kimliği Kapsamında Festivallerin Değerlendirilmesi: Uluslararası Altın Safran Film Festivali Örneği, Turizm ve Araştırma Dergisi, 2(1): 57-69.

Schneider, I. E. and Backman, S. J. (1996). Cross-Cultural Equivalence of Festival Motivations: A Study in Jordan, Festival Management and Event Tourism, 4(3-4): 139-144.

Scott, D. (1995). A Comparison of Visitors' Motivations to Attend Three Urban Festivals, Festival Management and Event Tourism, 3(3): 121-128.

Song, H. J., Bae, S. Y., and Lee, C. K. (2017). Identifying Antecedents and Outcomes of Festival Satisfaction, International Journal of Contemporary Hospitality Management, 29(3): 947-965.

Sthapit, E., Del Chiappa, G., Coudounaris, D. N., and Björk, P. (2019). Tourism Experiences, Memorability and Behavioural Intentions: A Study of Tourists in Sardinia, Italy, Tourism Review, 75(3): 533-558.

Tanford, S. and Jung, S. (2017). Festival Attributes and Perceptions: A Meta-Analysis of Relationships with Satisfaction and Loyalty, Tourism Management, 61: 209-220.

Tayfun, A. ve Arslan, E. (2013). Festival Turizmi Kapsaminda Yerli Turistlerin Ankara Alışveriş Festivali'nden Memnuniyetleri Üzerine Bir Araştırma, İşletme Araştırmaları Dergisi, 5(2):191-206.

Thrane, C. (2002). Jazz Festival Visitors and Their Expenditures: Linking Spending Patterns to Musical Interest, Journal of Travel Research, 40(3): 281-286.

Türk Dil Kurumu Sözlükleri (2019). http://sozluk.gov.tr, [Erişim Tarihi 20.09.2019]

Ugurlu, H., and Ugurlu, E. G. (2011). Investigation on Audience of International Eskisehir Film Festival, Anadolu University Journal of Social Sciences, 11(3), 259-276.

Uğurlu, S. (2016). Lojistik Regresyon Analizi, C.O. Güzeller (Editör.), Herkes İçin Çok Değişkenli İstatistik içinde (ss. 132-151) Ankara: Maya Akademi.

Ural, A., ve Kılıç, İ. (2006). Bilimsel Araştırma Süreci ve SPSS ile Veri Analizi: SPSS 10.0-12.0 for windows, Ankara: Detay Yayıncılık.

Uysal, M., and Gitelson, R. (1994). Assessment of Economic Impacts: Festivals and Special Events, Festival Management and Event Tourism, 2(1): 3-9.

Uysal, M., Gahan, L., and Martin, B. (1993). An Examination of Event Motivations: A Case Study, Festival Management and Event Tourism, 1(1): 5-10.

Uysal, M., Backman, K., Backman, S., and Potts, T. (1991). An Examination of Event Tourism Motivations and Activities. New Horizons in Tourism and Hospitality Education, Training and Research: Conference, July 1991, Calgary, Canada.

Velikova, N., Slevitch, L., and Mathe-Soulek, K. (2017). Application of Kano model to identification of wine festival satisfaction drivers. International Journal of Contemporary Hospitality Management. Doi: 10.1108/IJCHM-03-2016-0177

Vinnicombe, T., and Sou, P. U. J. (2017). Socialization or Genre Appreciation: The Motives of Music Festival Participants, International Journal of Event and Festival Management, 8(3): 274-291. 
Walo, M., Bull, A., and Breen, H. (1996). Achieving Economic Benefits at Local Events: A Case Study of a Local Sports Event, Festival Management and Event Tourism, 4(3-4): 95-106.

Wu, H. C. and Ai, C. H. (2016). A Study of Festival Switching Intentions, Festival Satisfaction, Festival Image, Festival Affective Impacts, and Festival Quality. Tourism and Hospitality Research, 16(4): 359-384.

Yıldırım, O., Karaca, O. B., ve Çakıcı, C. (2016). Yerel Halkın Adana-Uluslararası Portakal Çiçeği Karnavalı'na Yönelik Algı ve Memnuniyetleri Üzerine Bir Araştırma, Seyahat ve Otel İşletmeciliği Dergisi, 13(2): 50-68.

Yolal M., Çetinel, F., and Uysal M. (2009). An Examination of Festival Motivation and Perceived Benefits Relationship: Eskişehir International Festival, Journal of Convention and Event Tourism, 10: 267-291.

Yolal, M. (2017). Türkiye'nin Etkinlik Turizmi Potansiyelinin Değerlendirilmesi, Uluslararası Turizm ve Sosyal Araştırmalar Dergisi, 2: 35-51.

Yolal, M., Özdemir, C. and Batmaz, B. (2019). Multidimensional Scaling of Spectators' Motivations to Attend a Film Festival, Journal of Convention and Event Tourism, 20(1): 64-83. 